\title{
Media Komik Matematika Perkalian untuk Tunarungu
}

\author{
Ismiatul Azizah, Moch Irvan \\ Universitas Negeri Malang \\ Email : azizahismie@gmail.com
}

\begin{abstract}
Abstrak: Penelitian ini berjudul efektivitas media komik matematika perkalian untuk meningkatkan kemampuan pemahaman anak tunarungu kelas V. Penelitian ini menghasilkan sebuah produk berbentuk media komik. Media komik matematika perkalian adalah media komik berupa kumpulan soal cerita dalam materi perkalian matematika yang dirancang untuk peserta didik tunarungu. Penelitian ini bertujuan untuk menganalisis efektivitas penggunaan komik matematika perkalian dalam meningkatkan kemampuan pemahaman pada siswa kelas V Tunarungu. Metode yang dipakai dalam penelitian ini adalah R \& D (Research and Development). Hasil pengembangan secara keseluruhan menunjukkan bahwa media komik perkalian matematika dinilai sangat efektif digunakan saat pembelajaran matematika dikelas.

Kata kunci : Komik Matematika Perkalian; Kemampuan Pemahaman; Tunarungu.
\end{abstract}

\begin{abstract}
This research is titled the effectiveness of multiplication comics math media to improve the ability of students with hearing impairment in class V. This research produces a product in the form of comic media. Mathematical multiplication comics media is a comic media in the form of a collection of story questions in mathematics multiplication material designed for deaf students. This study aims to analyze the effectiveness of the use of mathematical comic multiplication in improving the ability of understanding in class $\mathrm{V}$ students with hearing impairment. The method used in this research is $\mathrm{R}$ \& D (Research and Development). The results of the overall development showed that the mathematics multiplication comic media was considered very effective when using mathematics in class.
\end{abstract}

Keyword: Multiplication Comics; Understanding Ability; Deaf.

Dalam dunia pendidikan tidak akan ada batasannya dan tidak ada kata diskriminasi. Dari usia muda sampai tua pun berhak untuk memperolehkan pendidikan yang setara dengan yang lainnya. Hal ini juga berlaku bagi anak yang berkebutuhan khusus dengan berbagai macam kondisinya, mereka berhak memperoleh pendidikan yang sesuai dengan kemampuan mereka. Setiap anak berbeda, baik dari segi kemampuannya maupun kelemahan yang dimilikinya. Seperti Oleh karena itu, sebagai pendidik guru harus bisa mengetahui sejauh mana kemampuan yang dimiliki oleh anak tersebut dan bagaimana cara mendidiknya. Satu diantara beberapa hambatan yang dialami oleh anak yakni tunarungu.

Hanahan dan Kauffman (Wardani, Astati, Hernawati dan Somad, 2007) menyebutkan Tunarungu atau biasa disebut dengan hearing impairment yakni suatu penyebutan yang menunjukkan keterbatasan kemampuan pendengaran yang diklasifikasikan berdasarkan tingkat keparahannya

Jika ditinjau dari sisi akademis, kemampuan intelektual anak tunarungu sama dengan anak yang dapat mendengar yaitu mempunyai IQ yang normal, namun saat dilapangan kita sering menemui prestasi anak tunarungu rendah bahkan bisa dikatakan jauh tertinggal dengan anak yang dapat mendengar pada umumnya (Wardani, Astati, Hernawati dan Somad, 2007). Hal ini disebabkan karena kemampuan verbal anak tunarungu terbatas. Pelajaran verbal adalah pelajaran yang didominasi oleh bacaan yang memerlukan pemahaman pembacanya. Kondisi seperti ini terjadi karena perkembangan kecerdasan dan kemampuan berbahasa anak saling beiringan satu sama lain. Sedangkan kondisi sesungguhnya yang dialami oleh anak yakni sukar untuk memahami bahasa.

Seringkali kita jumpai dilapangan prestasi anak tunarungu kurang dari anak mendengar pada umumnya, itu semua tidak diakibatkan oleh faktor intelegensi anak yang rendah akan tetapi anak tunarungu tidak dapat menggunakan secara maksimal kemampuan intelegensi yang mereka miliki (Efendi, 2017). Pengetahuan maupun informasi yang berasal dari indera pendengaran maupun verbal seringkali rendah, namun pengetahuan yang berasal dari indera penglihatan dan motorik bisa berkembang sama cepatnya seperti anak mendengar pada umumnya. Bahkan anak tunarungu terkenal dengan anak yang mempunyai penglihatan yang sangat tajam, lebih tajam dari anak normal. Maksud dari penglihatan tajam disini, anak tunarungu sangat memaksimalkan indera mereka yang masih berfungsi. Oleh karena itu, mereka sangat was was dan sangat peka terhadap lingkungan bahkan orang orang disekitar mereka.

Durasi peningkatan kecerdasan anak tunarungu dengan anak mendengar seusianya tidak sama cepatnya. Anak yang normal atau yang bisa mendengar bisa belajar dari informasi yang didapat dari organ pendengarannya, dengan mendengar anak akan 
memperoleh banyak informasi, karena memang banyak hal yang kita tahu saat kita mendengar (Desmita, 2014).

Namun, hal ini tidak terjadi demikian bagi anak tunarungu. Mereka tidak memperoleh informasi apapun melalui pendengarannya, sehingga pengetahuan dan kemampuan berbahasa yang ia miliki juga sedikit, bahkan terkadang tidak memperoleh informasi apapun. Akibat dari sedikitnya informasi yang masuk dan kurangnya anak tunarungu dalam berbahasa juga menimbulkan keterbatasan saat mereka diajak untuk berkomunikasi, karena terbatasnya kosa kata yang ia peroleh. Wardani, Astati, Hernawati dan Somad (2007) menyatakan bahwa dalam memahami ungkapan atau istilah bahasa yang bermakna ambigu maupun bermakna tidak sebenarnya, anak tunarungu juga tidak bisa melakukannya, hal ini disebabkan karena mereka tidak bisa memahami sesuatu hal yang bersifat tidak nyata atau tidak berbentuk nyata.

Akibat dari terhambatnya informasi melalui indera pendengaran anak tunarungu, maka dari itu mereka harus memaksimalkan indera penglihatan mereka untuk mempelajari banyak hal. Namun, informasi bisa didapat saat anak membaca buku ataupun media cetak lainnya yang memiliki banyak pengetahuan. Kegiatan membaca tidak sekedar menyuarakan bunyi huruf, kata dan kalimat atau hanya sekedar mencari kata sulit kemudian diartikan dalam suatu teks. Tetapi lebih dari itu, saat membaca harus memahami apa yang sedang dibaca, dan tahu apa maksudnya.

Disamping terhambat dalam kemampuan berbahasa, anak tunarungu juga mempunyai hambatan dalam memahami bacaan. Kemampuan memahami bacaan sangat diperlukan oleh anak dalam berbagai mata pelajaran di sekolah, terutama dalam memahami soal cerita matematika. Persoalan yang ada dalam soal cerita berasal dari permasalahan umum yang ada dikehidupan sehari hari anak, sehingga anak akan lebih mudah untuk memahami saat mengerjakan soal tersebut.

Secara umum, setiap soal cerita cerita dalam pelajaran matematika mengandung konsep operai hitung matematika, yakni perkalian, pembagian, penjumlahan, dan pengurangan. Oleh karena itu, saat anak mengerjakan soal cerita, terlebih dahulu anak harus memahami apa yang ditanyakan lalu anak harus mengonversikan dalam bentuk angka dan menghitung hasil temuan yang terdapat salam soal tersebut.

Dengan demikian, anak melakukan beberapa proses didalamnya, yaitu proses pemahaman kalimat yang ada didalam soal cerita dan proses penerjemahan kalimat pada soal cerita menjadi bilangan. Saat melakukan penerjemahan kalimat soal cerita menjadi bilangan kemampuan membaca anak sangat dibutuhkan, terutama kemampuan membaca pemahamn. Saat anak memahami kata demi kata yang ada pada soal, perlahan ia akan tahu apa yang dimaksudkan dalam soal tersebut. Proses penerjemahan kalimat soal cerita akan berjalan baik jika anak tahu apa yang dimaksudkan dalam teks bacaan serta paham terhadap konsep operasi hitung, yakni perkalian, pembagian, penjumlahan serta pengurangan. Proses ini saling berkaitan satu dengan yang lainnya, tidak bisa jika hanya melakukan satu proses saja, karena keduanya sudah merupakan satu paket proses yang mutlak dilakukan saat memahami soal cerita matematika.

Saat anak memahami maksud dari soal cerita matematika tersebut, idealnya anak bisa membayangkan seolah olah dirinya yang menjadi tokoh utama dalam soal cerita tersebut. Sehingga anak faham apa yang harus ia lakukan saat menghadapi situasi atau kondisi yang sama dengan cerita. Setelah anak faham soal, barulah kemampuan operasi hitung matematika anak dibutuhkan.

Seperti yang disebutkan diatas, jalannya pemahaman soal cerita berawal dari pemahaman kalimat dalam soal cerita kemudian dilanjutkan dengan proses penerjemahan kalimat pada soal cerita menjadi angka. Namun, untuk anak tunarungu jika melewati dua tahapan pemahaman soal cerita tersebut akan sangat kesulitan. Karena soal yang berbentuk cerita bagi mereka itu abstrak. Sedangkan kendala anak tunarungu itu sendiri yaitu meahami sesuatu yang tak nyata atau bisa dikatakan abstrak. Maka dari itu, kemampuan pemahaman pada anak tunarungu bisa dikatakan lebih rendah dari pada anak normal seusianya.

Berbagai cara telah digunakan untuk meminimalisir dampak dari ketunarunguan tersebut. Untuk itu, media komik matematika ini dikembangkan untuk menjembatani kemampuan anak, agar bisa memaksimalkan aspek intelegensi yang dimilikinya.

Komik bukan hanya cerita bergambar yang lucu dan untuk menghibur para pembacanya saja, namun lebih dari itu, komik termasuk dalam media yang berbentuk visual yang digunakan untuk menyampaikan informasi - informasi terhadap para pembacanya. Menurut Waluyanto (2015) Komik termasuk dalam kategori media komunikasi visual unik karena menggabungkan unsur bacaan dan gambar dalam satu panel yang digunakan untuk menyampaikan pengetahuan seperti buku secara jelas dan mudah dicerna oleh para pembaca. Hal ini bisa terjadi karena, gambar dan tulisan dipadukan menjadi satu agar mempunyai makna kemudian dirangkai menjadi suatu alur cerita agar lebih mudah untuk dipahami dan dimengerti, sehingga secara tidak langsung informasi tersebut akan tertanam dalam memori ingatan para pembaca komik.

Budiarti \& Haryanto (2016) menyatakan bahwa peran komik sebagai media pembelajaran yakni sebagai perantara informasi dalam pembelajaran. Dalam sebuah pembelajaran tentunya terdapat proses penyampaian informasi dari sumber belajar terhadap anak. Proses pembelajaran bisa berjalan dengan baik jika penyampaian informasi dilakukan secara jelas, 
menarik serta sistematis Mengapa bisa dikatakan begitu, karena saat anak memahami apa yang disampaikan dalam pembelajaran melalui media, artinya media yang digunakan tersebut berhasil menyampaikan maksud dari materi yang ada. Namun, jika anak tidak memahami materi, bisa dikatakan media tersebut gagal untuk mengantar materi pada anak dan artinya media tersebut tidak efektif, dan bisa digunakan kembali jika sudah dilakukan perbaikan. Berdasarkan beberapa pernyataan tersebut, komik pembelajaran adalah media yang digunakan sebagai pengantar informasi pada anak, sehingga permasalahan yang dihadapi oleh anak dalam memahami suatu materi bisa diatasi menggunakan media.

Sebagai media pembelajaran visual, media komik matematika perkalian mempunyai keunggulan khusus jika digunakan dalam kegiatan pembelajaran. Keunggulan media komik matematika perkalian tidak hanya sebatas mempermudah anak didik menangkap informasi yang abstrak, menambah pembendaharaan kata bagi anak, memicu minat baca anak yang lebih tinggi. Namun, media komik matematika perkalian juga digunakan untuk mengenalkan informasi baru melalui karakter yang terdapat dalam komik. Selain itu, Komik dapat digunakan untuk memperkenalkan anak pada lingkungan sekitarnya, budaya serta nilai - nilai yang juga sangat bermanfaat bagi anak dalam kehidupan masyarakat nanti. Berdasarkan hasil kajian peneliti di SLB Islam Yasindo Tumpang pada saat pelajaran matematika, maka penelitian ini bertujuan menganalisis efektivitas penggunaan media komik matematika perkalian perkalian untuk meningkatkan kemampuan pemahaman siswa kelas V Tunarungu di SLB Islam Yasindo Tumpang.

\section{METODE}

Penelitian efektivitas penggunaan media komik matematika perkalian untuk meningkatkan kemampuan pemahaman siswa kelas V Tunarungu di SLB Islam Yasindo Tumpang menggunakan metode R \& D (Research and Development). Menurut Sugiyono (2018) metode penelitian yang digunakan untuk membuat produk tertentu serta menganalisis efektif suatu tidaknya suatu produk saat digunakan merupakan jenis penelitian pengembangan (Research \& Development). Menurut Borg \& Gall dalam Putra (2015, p.84) menyatakan bahwa prosedur penelitian pengembangan adalah penelitian bisa dirancang baru maupun dibuat baru yang berbeda dengan sebelumnya sesuai dengan kondisi dilapangan, namun tetap memiliki kriteria tertentu seperti keefektifan dan kualitas. Langkah-langkah rancangan dari Borg and Gall terdapat 10 tahapan, namun Metode penelitian pengembangan oleh Borg \& Gall adalah metode yang mudah untuk dipahami sehingga bisa disesuaikan dengan situasi dan kondisi peneliti. Dalam penelitian ini, pengembang memilih tujuh dari sepuluh langkah model pengembangan research and devlopment (R\&D) Borg and Gall. Pemilihan 7 langkah tersebut telah mempertimbangkan karakteristik yang akan diteliti serta terbatasnya waktu, tenaga serta biaya pengembang. Penelitian ini disederhanakan menjadi 7 tahapan yaitu: analisis kebutuhan, rancangan produk, pengembangan desain produk awal, validasi produk awal, revisi produk awal, uji coba produk, revisi produk akhir.

Subjek uji coba produk ini terdiri dari 3 validator yakni validator materi, validator praktisi dan validator media. Pengguna komik ini yakni semua siswa kelas V SLB Islam Yasindo yang berjumlah 6 orang dengan kemampuan rata-rata.

Teknik pengumpulan data dalam artikel ini melalui observasi, wawancara, angket dan dokumentasi. Observasi dilakukan untuk mengamati tempat yang akan digunakan untuk penelitian serta mengamati subjek yang akan diteliti yaitu anak kelas V-B SLB Islam Yasindo Tumpang. Wawancara dilakukan pada guru kelas V-B SLB Islam Yasindo Tumpang. Wawancara pada guru berguna untuk memahami kemampuan yang dimiliki oleh siswa serta problemproblem yang dihadapi oleh siswa dan guru dalam mengajar anak serta upaya guru yang telah dilakukan. Pedoman wawancara terdiri dari pokok persoalan yang akan dipertanyakan.

Dalam penelitian ini, angket digunakan untuk validasi validator materi, validator praktisi dan validator media. Dokumen terdiri dari banyak hal, ada yang berupa tulisan, foto, maupun karya sejarah. Banyak pendapat yang menyatakan jika hasil penelitian akan lebih akurat jika didukung oleh dokumentasi seperti foto, video, dll. Namun perlu diketahui, dokumentasi harus mencerminkan keadaan aslinya agar mempunyai nilai kredibilitas yang tinggi.

Teknik analisis data dalam penelitian ini adalah kualitatif dan kuantitatif. Data kualitatif berupa hasil observasi, wawancara dan angket (saran dan kritikan) dari para validator. Sedangkan data kuantitatif diperoleh dari angket yang telah diisi oleh para validator dan tes hasil belajar.

Dalam suatu penelitian dibutuhkan sebuah media yang layak dan sesuai dengan kebutuhan anak melalui validitas.

\section{HASIL DAN PEMBAHASAN}

\section{Hasil}

Validasi dilakukan oleh tiga validator, yakni validator validator, validator media dan validator praktisi. Hasil validator materi selain diperoleh data kuantitatif juga didapat data kualitatif berupa saran dan masukan yang berkaitan dengan komik perkalian matematika. 
Tabel 1. Data Hasil Uji Coba Kelompok Sebelum dan Saat Menggunakan Media

\begin{tabular}{lllllll}
\hline \multirow{2}{*}{ No } & \multirow{2}{*}{$\begin{array}{l}\text { Nama } \\
\text { Siswa }\end{array}$} & Soal & \multicolumn{2}{c}{$\begin{array}{l}\text { Sebelum meng- } \\
\text { gunakan media }\end{array}$} & \multicolumn{2}{c}{$\begin{array}{c}\text { Saat menggu- } \\
\text { nakan media }\end{array}$} \\
\cline { 3 - 7 } benar & Skor & benar & Skor \\
\hline 1. & NS & 10 & 4 & 40 & 9 & 90 \\
\hline 2. & EA & 10 & 3 & 30 & 9,5 & 95 \\
\hline 3. & SY & 10 & 4 & 40 & 10 & 100 \\
\hline 4. & FZ & 10 & 3 & 30 & 8 & 80 \\
\hline 5. & NF & 10 & 1 & 10 & 8 & 80 \\
\hline 6. & MI & 10 & 6 & 60 & 10 & 100 \\
\hline
\end{tabular}

Dengan rincian terdapat 10 butir pertanyaan dengan 8 butir instrumen yang memperoleh skor 4 dan 2 butir instrumen yang memperoleh skor 3. Berdasarkan data kuantitatif yang didapat dari hasil validator materi, komik perkalian matematika untuk anak tunarrungu kelas $\mathrm{V}$ memperolehkan skor $95 \%$. Dalam artian validator materi memberikan rekomendasi bahwa komik perkalian matematika ini sangat valid dan sangat layak digunakan dengan revisi kecil.

Validasi yang kedua dilaksanakan oleh validator media. Hasil validator media selain diperoleh data kuantitatif juga didapat data kualitatif berupa saran dan masukan yang berkaitan dengan komik perkalian matematika. Terdapat 10 butir pertanyaan dengan 9 butir instrumen yang memperoleh skor 4 dan 1 butir instrumen yang memperoleh skor 3. Berdasarkan data kuantitatif yang didapat dari hasil validator media komik perkalian matematika untuk anak tunarungu kelas V memperolehkan skor 97,5\%. Dalam artian validator materi memberikan rekomendasi bahwa komik perkalian matematika ini sangat valid dan sangat layak digunakan dengan revisi kecil.

Validasi yang ketiga dilakukan oleh validator praktisi. Hasil validator praktisi selain diperoleh data kuantitatif juga didapat data kualitatif berupa saran dan masukan yang berkaitan dengan komik perkalian matematika. Terdapat 10 butir pertanyaan dengan 7 butir instrumen yang memperoleh skor 4 dan 3 butir instrumen yang memperoleh skor 3. Berdasarkan data kuantitatif yang didapat dari hasil validator materi, komik perkalian matematika untuk anak tunarrungu kelas V memperolehkan skor 92,5\%. Dalam artian validator materi memberikan rekomendasi bahwa komik perkalian matematika ini sangat valid dan sangat layak digunakan dengan revisi kecil.

Kesimpulan tingkat kelayakan media secara keseluruhan dapat dianalisis dengan menghitung data yang didapatkan dari uji validitas yang dilakukan oleh validator materi, validator materi 2 , dan validator media menunjukkan tingkat kelayakan sebesar 95\% dengan kategori sangat layak digunakan.

Setelah melalui tahap validasi oleh validator materi, validator praktisi dan validator media. Media komik terlebih dahulu direvisi sebelum produk diujicobakan. Berikut ini hasil perbaikan produk yang didasarkan pada masukan validator materi dan validator praktisi adalah sebagai berikut :1) Jumlah gambar harus sesuai dengan soal, misalnya pada soal bagian 3, jika jumlah sepeda motor yang ada pada soal sebanyak 18 buah, maka gambar pada soal harus 18 buah tidak boleh lebih ataupun kurang. 2) Penggunaan kata bagian diganti dengan kata potong, misalnya pada bagian 4 kata yang seharusnya digunakan "2 potong ikan" bukan "2 bagian ikan" Kata bagian yang terdapat pada soal menimbulkan makna ganda, yakni siswa akan mengganggap soal itu sebagai soal pembagian.

Berdasarkan analisis data uji validator media telah diperoleh hasil revisi sebagai berikut : 1) Pada bagian sampul komik dibuat dua lembar, yakni sampul utama dan sampul kedua, untuk sampul kedua tanpa animasi kartun. 2) Pada bagian 2 dalam suasana pasar ikan sebaiknya setting pasarnya diberi tulisan dalam bahasa indonesia, agar tidak bingung. 3) Gambar pak kusir pada bagian 3 sebaiknya disketsa ulang agar tidak pecah. 4) Pada gambar tahu sumedang gambar cabainya dihilangkan saja. 5) Gambar sebaiknya diberi nomor halaman. Setelah produk direvisi sesuai dengan saran yang diberikan, Komik perkalian matematika ini diujicobakan pada subyek uji coba yaitu, siswa tunarungu kelas $\mathrm{V}$ yang berjumlah 6 orang anak. Berikut data hasil uji coba kelompok.

Berdasarkan data penilaian yang dilakukan sebelum menggunakan media komik, semua siswa kelas $\mathrm{V}$ tunarungu yang berjumlah 6 orang dinyatakan tidak lulus atau memperolehkan nilai kurang dari KKM (Kriteria Ketuntasan Minimum). Sedangkan penilaian yang dilakukan saat menggunakan media komik, semua siswa kelas $\mathrm{V}$ tunarungu yang berjumlah 6 orang dinyatakan lulus atau memperolehkan nilai lebih dari KKM (Kriteria Ketuntasan Minimum).

Kesimpulan yang didapat dari hasil uji coba terhadap siswa kelas V SLB Islam Yasindo adalah terjadinya peningkatan pada nilai hasil belajar siswa, sehingga media komik matematika perkalian ini sangat layak untuk digunakan dalam pembelajaran matematika di kelas.

\section{Pembahasan}

\section{Kajian Produk Berdasarkan Substansi}

Hasil kajian produk secara substansi ini dapat dilihat dan diuraikan berdasarkan hasil validasi dari validator materi. Secara garis besar, aspek yang dinilai atau divalidasi adalah aspek isi dan kebahasaan.

Aspek isi dari media komik ini disusun sesuai 
dengan Standar Kompetensi dan Kompetensi Dasar pada kurikulum 2013 untuk kelas V semester 2. Penilaian dari validator materi dan validator praktisi untuk aspek kesesuaian isi komik dengan Kompetensi Dasar, Tujuan Pembelajaran dan Indikator. Standar Kompetensi yang digunakan pada materi media ini yakni SK 3 \& 4 dengan Kompetensi Dasar 3.1 dan 4.1.Standar Kompetensi 3 \& 4 dan Kompetensi Dasar 3.1 \& 4.1 dipilih karena media ini menyesuaikan dengan tema yang sedang dipelajari di kelas $\mathrm{V}$ yakni tentang teknologi transportasi dan ekonomi (Tema 4) dengan subtema Teknologi Transportasi (Sub Tema 1).

Keterkaitan cerita dengan kehidupan sehari - hari, memperolehkan nilai sangat layak. Hal ini didasarkan pada teori contextual learning atau pembelajaran kontekstual yang mempunyai asumsi bahwa secara natural pikiran mencari makna konteks sesuai dengan situasi nyata lingkungan seseorang melalui pencarian hubungan masuk akal dan bermanfaat. Pengetahuan yang diterima oleh anak di sekolah akan lebih bermakna jika dikaitkan dengan kehidupan sehari hari anak. Nantinya siswa akan menggunakan pengetahuannya tersebut untuk menyelesaikan masalah - masalah baru yang belum pernah dihadapinya (Prihanto \& Yunianta, 2018).

Pada poin ketepatan dialog / teks dengan soal cerita, validator materi dan validator praktisi memberikan nilai layak. Hal ini dikarenakan, dialog yang terdapat pada komik sudah relevan dengan soal cerita yang terdapat diakhir setiap bagian, namun validator validator materi memberikan masukan agar meneliti kembali jumlah gambar yang ada pada soal diakhir setiap bagian.

Pada poin ketepatan penggunaan ilustrasi dalam soal cerita memperolehkan nilai sangat layak. Hal ini dikarenakan, setting setiap bagian disesuaikan dengan judul bagian. Misalnya pada bagian dua judul bagiannya kegiatan dipasar ikan, maka setting tempat maupun suasana pada komik dibuat sesuai judul, yakni suasana di pasar ikan. hal ini dilakukan untuk mendukung konsep pembelajaran kontekstual pada komik.

Kebenaran konsep materi soal jika ditinjau dari aspek keilmuan memperolehkan nilai sangat layak. Hal ini dikarenakan, materi yang terdapat pada komik yakni konsep perkalian sama dengan kurikulum yang diterapkan di SLB.

Jika ditinjau dari aspek kebahasaan. Bahasa yang digunakan komunikatif memperolehkan nilai sangat layak. Hal ini dikarenakan, pembaca mudah memahami maksud yang disampaikan melalui media komik ini. Menurut Kamus Besar Bahasa Indonesia (KBBI) bahasa yang komunikatif adalah bahasa yang mudah dimengerti, sehingga yang dimaksudkan oleh penulis bisa tersampaikan dengan baik kepada pembaca.

Pada poin bahasa dalam dialog sudah menarik. Hal ini dikarenakan dialog yang digunakan seperti dialog yang diucapkan sehari - hari. Selain itu dialog pada komik pendek, tidak bertele - tele, anak akan mempunyai kesan tersendiri saat melihat dialog pada komik hanya sedikit. Jadi, anak akan lebih tertarik untuk membacanya.

Pada poin kesesuaian kata dengan taraf berfikir anak memperolehkan nilai sangat layak. Hal ini dikarenakan, dalam pemilihan kata untuk dialog ataupun gaya yang digunakan dalam komik harus sesuai dengan tingkatan usia anak, karena setiap anak mempunyai tingkat pemahaman yang berbeda - beda. Menurut Tabrani (Suharjanto, 2006) peranan verbal dalam komik sebagai pengungkap ujaran narasi dan mendeskripsikan situasi sehingga pembaca mengetahui situasi yang terjadi dalam komik. Saat usia SD, anak lebih suka bahasa yang semangat, riang gembira. Anak SD pun belum bisa memahami kata yang mempunyai makna banyak, sehinggga bahasa yang digunakan juga di permudah agar mudah untuk dipahami.

Pada poin, kemudahan memahami jalannya cerita melalui bahasa memperolehkan nilai layak. Hal ini disebabkan karena bahasa pada komik sudah cocok dengan taraf berfikir anak, yakni anak usia sekolah dasar sehingga anak akan lebih mudah saat memahami alur cerita. Masukan dari beberapa validator dialog pada percapakan dalam komik harus dinaikkan sedikit tingkat kesulitannya, karena menurut beliau ada beberapa dialog yang masih terlalu mudah.

pada poin ketepatan kata tidak bermakna ganda, validator materi memberikan nilai sangat layak sedangkan validator praktisi memberikan nilai layak. Menurut KBBI, makna ganda yakni satu kata mempunyai makna banyak sehingga menimbulkan ketidakjelasan informasi yang dibaca.

Sudjana, Nana, \& Rivai (2010) menyebutkan bahwa kesesuaian media digunakan dalam pembelajaran, validator praktisi memberikan nilai sangat layak. media komik yang digunakan dalam proses belajar mengajar bisa menimbulkan minat belajar siswa.

\section{Kajian Produk Berdasarkan Teknis}

Hasil kajian produk secara teknis ini dapat dilihat dan diuraikan berdasarkan hasil validasi dari validator media. Secara garis besar, aspek yang dinilai atau divalidasi adalah aspek gambar komik dan tampilan menyeluruh.

Jika ditinjau dari Aspek Gambar Komik. gambar yang digunakan dalam media komik perkalian ini dinilai sangat layak untuk dimanfaatkan dalam pembelajaran. Hal ini dikarenakan karakter tokoh yang disajikan dalam komik sudah tepat dan menarik untuk pembaca, yakni siswa tingkat Sekolah Dasar. Dalam media komik ini karakter pada komik seperti nyata, karena gambar yang ada didalam komik hampir sama bentuknya dengan yang asli dalam artian tidak ada bagian tubuh yang dilebih-lebihkan. Yonkie \& 
Nugroho (2018) menyatakan bahwa dalam membuat ilustrasi karakter atau tokoh dalam komik proporsi tubuh dibuat menyerupai anatomi asli manusia, namun beberapa komponen ada yang disederhanakan seperti wajah.

Pada poin kesesuaian ekspresi dan dialog pada tokoh, validator media memberikan nilai layak. Menurut Berger (Suharjanto, 2006) Ekspresi wajah yang berguna untuk menciptakan karakter tokoh dalam berbagai perasaan. Sedangkan dialog yang ada pada balon kata setiap panel akan menunjukkan ungkapan perasaan atau ekspresi tokoh pada saat itu. Validator media memberikan masukan agar lebih teliti lagi dalam membuat ekspresi tokoh, karena ada satu gambar yang tidak jelas.

Menurut Berger (Suharjanto, 2006) Pada poin kesesuaian penggambaran latar dan suasana dengan cerita, aspek penggambaran latar bertujuan untuk menjelaskan situasi yang sedang terjadi didalam komik. validator media memberikan nilai sangat layak, karena suasana yang tergambar dalam komik sesuai dengan kenyataan.

Berdasarkan poin Pewarnaan dalam komik menarik, validator media memberikan nilai sangat layak. Hal ini dikarenakan, pewarnaan pada komik juga menjadi hal yang sangat crusial untuk diperhatikan. Menurut McCloud (Yonkie \& Nugroho, 2018) menyatakan bahwa perbedaan komik hitam - putih dan komik warna sebagai sesuatu yang luas dan mendalam yang akan mempengaruhi pengalaman membaca para audience. Dalam komik hitam - putih, ide yang mendasari seni didalam komik dikomunikasikan secara langsung, sedangkan komik berwarna memiliki ruang lebih banyak untuk bereksplorasi dan berekspresi. Oleh karena itu, pewarnaan pada media komik matematika yang dikembangkan menggunakan pewarnaan yang beragam, karena sebagian besar anak menyukai gambar dengan perpaduan berbagai macam warna, perpaduan warna - warna yang cantik tersebut menunjukkan keceriaan yang sesuai dengan karakter anak tingkat Sekolah Dasar (Indaryati \& Jailani, 2015).

Pewarnaan pada background juga dibuat satu tema dengan warna pada sampul. Namun, untuk background setiap bagian dibuat lebih soft daripada warna sampul agar warna tersebut kontras dengan warna pada setiap panel sehingga mudah untuk membedakannya. Sebuah warna dipilih dalam tampilan media visual dengan mempertimbangkan dua hal. Hal pertama adalah dari segi pemberian dampak yang selaras dibandingkan dengan yang lain, dan pertimbangan kedua dipilih dengan mempertimbangkan dampak emosi warna tersebut (Sudhata., Wawan, \& Tengeh, 2009).

Secara keseluruhan pada aspek tampilan menyeluruh ini memperolehkan nilai sangat layak dari validator media. Hal ini dikarenakan ukuran gambar, tulisan dalam dialog dan juga pengaturan serta penempatan frame atau panel cukup jelas. Jenis tulisan yang digunakan dalam dialog pada komik perkalian matematika ini adalah Comic San MS dengan ukuran font 14. Font ini digunakan karena style tulisan menarik dan cocok digunakan untuk komik. Warna dialog pada masing-masing balon kata menggunakan warna hitam, karena warna ini netral untuk dipadukan dengan bermacam - macam warna pada komik sehingga mudah dilihat dan dibaca.

Menurut Loomis (Yonkie \& Nugroho, 2018) menyatakan bahwa garis dalam panel digunakan untuk membagi atau membatasi sebuah ruang atau area untuk memberikan konsep awal suatu komposisi komik. Balon kata adalah indikator kepada pembaca yang menunjukkan siapa yang mengucapkan suatu hal dan bagaimana tokoh tersebut mengucapkannya. Bentuk balon teks dapat bervariasi tergantng situasi yang dialami oleh tokoh. Namun, menurut Alvares (Yonkie \& Nugroho, 2018) penempatan balon teks tidak bisa seenaknya agar tidak menghalangi informasi visual yang disampaikan

Terkait dengan pengemasan media, kemasan media ini menggunakan jilid spiral. Jilid spiral dipilih karena lebih bagus dan lebih menarik dibandingkan dengan jilid lainnya. Jilid ini juga dipilih sebagai alternatif karena media komik matematika ini jumlah halamannya sedikit. Selain itu, jilid spiral ini juga memudahkan siswa saat menggunakan komik ini, agar mudah dibalik tanpa meninggalkan lipatan pada lembar komik.

\section{KESIMPULAN DAN SARAN}

\section{Kesimpulan}

Mengacu pada hasil penelitian maupun pembahasan diatas ditemukan perbedaan skor siswa antara sebelum dan saat menggunakan media komik matematika perkalian sebagai media pembelajaran di kelas, maka kesimpulan yang didapat yakni media komik matematika yang dikembangkan oleh peneliti dinilai efektif meningkatkan kemampuan pemahaman anak tunarungu kelas $\mathrm{V}$ di SLB Islam Yasindo Tumpang. Hal ini dibuktikan dengan hasil nilai siswa kelas $\mathrm{V}$ sebelum menggunakan media dan saat menggunakan media komik mengalami peningkatan.

\section{Saran}

Peneliti memberikan saran pemanfaatn bagi guru, siswa dan bagi pengembang selanjutnya. Saran pemanfaatan bagi guru adalah : 1) Guru sebaiknya mempelajari terlebih dahulu materi yang ada didalam media komik ini sebelum menggunakannya, 2) Media ini bisa digunakan kepada anak dengan hambatan lain, dengan catatan kemampuan anak tersebut sama atau diatas anak kelas V B SLB Islam Yasindo Tumpang, 3) Guru juga dapat menggunakan media ini sebagai 
sumber belajar saat materi bermain peran, 4) Guru diharapkan dapat mempunyai kreativitas dalam mengembangkan media pembelajaran bagi siswa seperti komik ini. Karena bagi anak berkebutuhan khusus media sangat dianjurkan untuk mempermudah mereka memahami materi yang diajarkan, apalagi untuk anak tunarungu, akan lebih baik lagi jika mereka sering diberikan media visual.

Saran pemanfaatan bagi anak adalah : Anak harus sering berlatih mengerjakan soal cerita menggunakan komik ini, karena dengan begitu kemampuan pemahaman dalam memahami soal semakin lama akan meningkat, anak bisa menggunakan ilmu yang telah diperoleh dikehidupan nyata mereka.

Saran bagi pengembang yang akan memproduksi media yang sama, hasil penelitian ini bisa dijadikan sebagai salah satu rujukan dalam pengembangan media komik dengan tema yang berbeda serta bisa memotivasi pengembang selanjutnya agar bisa memberikan inovasi baru dalam dunia pendidikan sehingga dapat memotivasi siswa agar belajar lebih baik lagi.

\section{DAFTAR PUSTAKA}

Budiarti, W.N., \& Haryanto, H. (2016). Pengembangan Media Komik Untuk Meningkatkan Motivasi Belajar Dan Keterampilan Membaca Pemahaman Siswa Kelas IV. Jurnal Prima Edukasia, 4(2), 233-242.

Desmita. (2014). Psikologi Perkembangan Peserta Didik. Bandung : Remaja Rosdakarya
Efendi, M. (2017). Pengantar Psikopedagogik Anak Berkelainan. Malang: Universitas Negeri Malang

Indaryati \& Jailani. (2015). Pengembangan media komik pembelajaran matematika meningkatkan motivasi dan prestasi belajar siswa kelas V. Jurnal Prima Edukasia, 3(1), 84-96.

Prihanto S, D.A., \& Yunianta, T.N.H. ( 2018) . Pengembangan media komik matematika pada materi pecahan untuk siswa kelas V Sekolah Dasar. Jurnal sains dan seni ITS. 5(1), 79-90.

Putra, N. (2015). Research \& Development: Penelitian dan Pengembangan Suatu Pengantar. Jakarta : Rajawali Pers

Sudhata., Wawan, I. G., \& Tengeh, I. M. (2009). Desain Multimedia Pembelajaran. Singaraja : Universitas Pendidikan Ganesha

Sudjana., Nana., \& Rivai,A. (2010). Media Pengajaran. Bandung : Sinar Bandung Algensindo

Suharjanto, A. (2006). Desain Street Inlet Berdasarkan Geometri Jalan. Jurusan Teknik Sipil, Fakultas Teknik Universitas Brawijaya : Malang

Sugiyono. (2018). Metode Penelitian Kuantitatif Kualitatif dan R\&D. Bandung: Alfabeta.

Waluyanto, H.D. (2015). Komik sebagai media komunikasi visual pembelajaran. Nirmana, 7(1),45-55.

Wardani, I.G.A.K., Astati., Hernawati,T., Somad, P. (2007). Pengantar Pendidikan Luar Biasa. Jakarta : Universitas Terbuka

Yonkie, A \& Nugroho, A. (2019). Unsur - unsur grafis dalam komik WEB. Dimensi DKV, 2(2), 123-134. 